\title{
PENERAPAN TEKNOLOGI PESTISIDA NABATI DAUN PEPAYA UNTUK PENGENDALIAN HAMA TERUNG
}

\author{
Application of Papaya Leave Vegetable Pesticide Technology \\ for Eggplant Pest Control
}

\author{
Vandalisna $^{1}$, Sugeng Mulyono ${ }^{2}$, dan Budi Putra ${ }^{2}$ \\ ${ }^{1}$ Politeknik Pembangunan Pertanian Gowa \\ ${ }^{2}$ Balai Besar Pelatihan Pertanian Batangkaluku, Gowa \\ e-mail: vandachaniago9@gmail.com
}

Received: 2 Mei 2021; Accepted: 27 Mei 2021; Published: 25 Juni 2021

\begin{abstract}
ABSTRAK
Penelitian bertujuan untuk mengetahui tingkat adopsi petani tentang penggunaan pestisida nabati daun pepaya untuk pengendalian hama pada tanaman terung dan menganalisis perubahan pengetahuan, sikap, dan keterampilan petani dalam membuat dan mengaplikasikan pestisida nabati daun pepaya sebagai pestisida alternatif terhadap pengendalian hama tanaman terung. Penelitian dilaksanakan di Kelompok Wanita Tani Bunga Tulip Kelurahan Bontoramba Kecamatan Somba Opu Kabupaten Gowa Provinsi Sulawesi Selatan. Berlangsung dari Bulan Februari sampai Juni 2019. Metode yang digunakan adalah demonstrasi plot dan metode survei. Metode demonstrasi plot dengan menggunakan dua perlakuan yaitu perlakuan $0,25 \mathrm{ml}$ pestisida anorganik/liter air, yang digunakan $=800 \mathrm{ml}(\mathrm{P} 1)$ dan $20 \mathrm{ml}$ pestisida nabati daun pepaya/liter air, yang digunakan $=800 \mathrm{ml}(\mathrm{P} 2)$. Aplikasi pestisida nabati daun papaya pada tanaman terung dapat mengendalikan hama tanaman terung secara efektif dengan dosis $20 \mathrm{ml} /$ liter air, menekan intensitas serangan hama tanaman terung hasil perlakuan terbaik yaitu pestisida nabati daun pepaya (P2) dengan hasil berbeda nyata $0,76 \%$ sedangkan pestisida anorganik (P1) $1,71 \%$. Hal demikian karena pestisida nabati daun pepaya memiliki bahan aktif papain baik secara langsung maupun secara sistemik dapat mengurangi aktivitas hama dan bahkan hama akan mati. Sebelum dan sesudah penyuluhan dilaksanakan evaluasi untuk mengetahui sejauhmana tingkat adopsi terhadap pengetahuan, sikap dan keterampilan petani tentang penerapan teknologi pestisida nabati daun pepaya untuk pengendalian hama terung. Hasil evaluasi penyuluhan menunjukan respons petani terhadap pestisida nabati daun pepaya pada tanaman terung menunjukan peningkatkan pengetahuan 32,8\%, sikap 33,7\% dan keterampilan 33,5\%. Pelaksanaan penyuluhan dinyatakan $69,7 \%$ berada pada kategori Efektif.
\end{abstract}

Kata kunci: Penerapan, pestisida, daun pepaya

\begin{abstract}
This study aims to determine the level of farmer adoption of the use of papaya leaf vegetable pesticides for pest control on eggplant and to analyze changes in farmers' knowledge, attitudes, and skills in making and applying papaya leaf vegetable pesticides as an alternative pesticide for eggplant pest control. The research was carried out in the Flower Tulip Farmer Women's Group, Bontoramba Village, Somba Opu District, Gowa Regency, South Sulawesi Province. Takes place from February to June 2019. The methods used are demonstration plots and survey methods. The plot demonstration method used two treatments, namely $0.25 \mathrm{ml}$ of inorganic pesticide/liter of water, used $=800 \mathrm{ml}(\mathrm{Pl})$ and $20 \mathrm{ml}$ of papaya leaf vegetable pesticide/liter of water, used $=800 \mathrm{ml}(\mathrm{P} 2)$. The application of papaya leaf vegetable pesticides on eggplant plants can control eggplant pests effectively with a dose of $20 \mathrm{ml} /$ liter of water, suppressing the intensity of eggplant pest attacks. The best treatment results are papaya leaf vegetable pesticides $(P 2)$ with significantly different results $0.76 \%$ while pesticides inorganic (P1) $1.71 \%$. This is because the papaya leaf vegetable pesticide has the active ingredient papain, either directly or systemically, it can reduce pest activity and
\end{abstract}


even the pests will die. Before and after the extension, an evaluation was carried out to determine the extent of adoption of the knowledge, attitudes and skills of farmers regarding the application of papaya leaf vegetable pesticide technology for eggplant pest control. The results of the extension evaluation showed that the response of farmers to papaya leaf pesticides on eggplant showed an increase in knowledge of $32.8 \%$, attitudes $33.7 \%$ and skills $33.5 \%$. The implementation of counseling stated that $69.7 \%$ were in the Effective category.

\section{Keywords: Application, pesticides, papaya leaf}

\section{PENDAHULUAN}

Terung (Solanum melongena L) merupakan tanaman asli daerah tropis berasal dari India dan Burma. Terung merupakan sayuran yang umum dibudidayakan dan dikonsumsi di Indonesia. Terung termasuk dalam famili Solanacea, satu keluarga dengan tanaman cabai, tomat dan kentang (Suharyon, et al, 2010; Dasipah, et al, 2010). Terung merupakan komoditi hortikultura yang memiliki nilai ekonomi tinggi. Buah terung sering dijadikan sebagai sayur dalam melengkapi lauk pada makanan sehari-hari dan dapat juga dijadikan aneka makanan ringan atau cemilan (Kadir, et al, 2015). Rendahnya hasil terung dapat disebabkan oleh berbagai faktor yaitu : tanah yang kurang subur, tindakan budidaya yang kurang baik, kondisi iklim yang kurang mendukung serta kurangnya keahlian petani dalam menganalisis secara lebih akurat tentang kondisi dan tingkat produktivitas tanaman tersebut (Duaja, et al, 2013).

Kendala utama dalam meningkatkan produksi terung didaerah tropis adalah serangan hama dan penyakit. Buah terung merupakan produksi utama, jika buah terung terserang hama mengakibatkan terjadinya penurunan produksi yang cukup tinggi dan sangat berpengaruh pada kualitas buah terung sehingga dapat mengakibatkan gagal panen dan kerugian buat petani (Wowor, et al, 2017). Berbagai usaha untuk mengendalikan hama dan penyakit tanaman telah dilakukan. Namun sampai saat ini masih tetap tertumpu pada penggunaan pestisida sintetis. Penggunaan pestisida secara terus menerus pada tanaman terung akan mengakibatkan biaya produksi meningkat, sehingga mengakibatkan harga menjadi tinggi (Srinivasan, 2009).

$$
\text { Penggunaan pestisida dapat }
$$

meninggalkan residu yang dapat menyebabkan pencemaran terhadap lingkungan dan gangguan pada kesehatan manusia (Chen, et al, 2011).
Selain itu pestisida sintetis yang digunakan terus menerus menyebabkan resistensi hama, resurgensi hama, timbulnya hama sekunder, mematikan serangga menguntungkan dan musuh alami (Pracaya, 2007).

Penggunaan pestisida sintetis yang dinilai praktis untuk mengendalikan serangan hama nyatanya memberikan dampak negative bagi lingkungan sekitar bahkan bagi penggunanya sendiri, sehingga dibutuhkan suatu alternatif lain yang dampak negatifnya kecil seperti pestisida yang bahan dasarnya berasal dari tumbuhan yang relative mudah dibuat dan bersifat mudah terurai (Grdisa dan Grsic, 2013). Pemanfaatan tumbuhan sebagai bahan aktif, pestisida mulai banyak digunakan untuk pengendalian hama dan penyakit. Hal ini dikarenakan sumber bahan kimia potensial yang dapat digunakan sebagai pestisida yang ramah lingkungan dan aman secara Kesehatan (Wiratno dan Trisawa, 2012).

Di Indonesia, bahan pestisida nabati banyak tersedia di alam dan baru dimanfaatkan sekitar satu persen. (Djunaedy, 2009). Pestisida nabati mempunyai manfaat, antara lain: dapat mengendalikan hama seperti aphid, rayap, hama kecil, dan ulat bulu serta berbagai jenis serangga, yang digunakan adalah daun pepaya karena daun pepaya (Carica papaya L.) mengandung senyawa toksik seperti saponin, alkaloid karpain, papain, flavonoid yang dapat mengendalikan hama terung seperti ulat, penghisap (kutu daun, trips, tungau), aphids, rayap dan ulat bulu (Intan, 2012).

Kandungan daun pepaya diantaranya senyawa papain merupakan racun kontak yang masuk ke dalam tubuh serangga melalui lubanglubang alami dari tubuh serangga. Senyawa papain juga bekerja sebagai racun perut yang masuknya melalui alat mulut pada serangga. Kemudian cairan tersebut masuk kedalam tubuh hama melalui lubang-lubang alami dari tubuhnya dan menyerang sistem syaraf sehingga dapat mengganggu aktifitas hama (Untung, 2006). 
Ekstrak daun papaya juga mengandung papain sebagai enzim protease. Ekstrak ini dapat digunakan bahan pengendalian dalam bidang pertanian sehingga mengurangi masalah gangguan hama pertanian, mempercepat produksi serta mengurangi resiko pada lingkungan (Jeana, et al, 2013).

Potensi tanaman pepaya mudah didapat karena masyarakat banyak yang membudidayakannya baik pada pekarangan rumah maupun lahan usahatani. Namun keterbatasan pengetahuan, sikap dan keterampilan petani yang masih kurang sehingga dapat katakan bahwa perlu adanya teknologi baru yang harus diberikan kepada petani setempat, yaitu pestisida berasal dari tanaman pepaya dapat digunakan untuk pengendalian hama terutama pada tanaman terung. Untuk mengetahui tingkat adopsi petani tentang penggunaan pestisida nabati daun pepaya untuk pengendalian hama pada tanaman terung dan menganalisis perubahan pengetahuan, sikap, dan keterampilan petani dalam membuat dan mengaplikasikan pestisida nabati daun pepaya sebagai pestisida alternatif terhadap pengendalian hama tanaman terung.

\section{METODE PENELITIAN}

Penelitian dilaksanakan di Kelompok Wanita Tani Bunga Tulip Kelurahan Bontoramba Kecamatan Somba Opu Kabupaten Gowa Provinsi Sulawesi Selatan. Berlangsung dari Bulan Februari sampai Juni 2019.

Metode yang digunakan adalah demonstrasi plot dan metode survei. Metode demonstrasi plot dengan menggunakan dua perlakuan yaitu perlakuan $0,25 \mathrm{ml}$ pestisida anorganik/liter air, yang digunakan $=800 \mathrm{ml}(\mathrm{P} 1)$ dan $20 \mathrm{ml}$ pestisida nabati daun pepaya/liter air, yang digunakan $=800 \mathrm{ml}(\mathrm{P} 2)$.

Data primer diperoleh dari hasil wawancara langsung dengan responden serta menggunakan daftar kuisioner. Observasi lapangan yaitu mengadakan pengamatan langsung ke lahan usahatani. Data sekunder dan studi pustaka merupakan data pendukung yang diperoleh dari kantor kelurahan, dinas atau instansi pertanian dan berbagai sumber yang terkait dengan materi penelitian.
Data dianalisis dengan menggunakan standar uji statistik (uji t) atau standar error menggunakan program exel, untuk mengetahui perbedaan hasil antara kedua perlakuan. Uji standar error dihitung dengan menggunakan rumus menurut (Kerlinger, 2004).

$$
\mathrm{SE}=\frac{\mathrm{Sd}}{\sqrt{\mathrm{n}}}
$$

Sedangkan untuk standar deviasi menggunakan persamaan:

$$
S d=\frac{S^{2}}{\sqrt{/ n}}
$$

Untuk mengukur tingkat adopsi responden terhadap penyuluhan penerapan teknologi pestisida nabati daun papaya untuk pengendalian hama terung dengan menggunakan rumus persentasi nilai dan diukur dengan garis continuum (Padmowihardjo, 2002).

$$
\begin{array}{r}
\text { T. Pengetahuan }=\frac{\text { Jumlah Jawaban }}{\text { Nilai Tertinggi }} \times 100 \% \\
\text { Efektivitas penyuluhan (ETP) dapat }
\end{array}
$$
dihitung dengan menggunakan rumus:

$$
\mathrm{EP}=\frac{\mathrm{Ps}-\mathrm{Pr}}{\mathrm{N} 4 \mathrm{Q}-\mathrm{Pr}} \times 100 \%
$$

\section{HASIL DAN PEMBAHASAN}

\section{Intensitas Serangan Hama}

Hasil penelitian untuk membandingkan dari dua perlakuan aplikasi pestisida anorganik (decis) dengan dosis $0,25 \mathrm{ml} /$ liter air (P1) dan pestisida nabati daun pepaya $20 \mathrm{ml} /$ liter air (P2) terhadap pengendalian hama tanaman terung dengan parameter Intensitas serangan hama yang menimbulkan gejala kerusakan bervariasi ( $\%$ helaian daun yang rusak), jumlah sampel dipilih dengan berbentuk zigzag sebanyak 20 tanaman pada setiap bedengan dari 100 populasi tanaman.

Hasil pengamatan intensitas serangan hama yang dilakukan mulai pada umur tanaman satu minggu sampai dengan enam minggu setelah tanam. Hasil analisis uji statistik Standar Error (SE) terhadap intensitas serangan hama tanaman terung pada minggu pertama dan kedua setelah tanam belum ada serangan hama, tetapi pada minggu ke tiga sampai enam setelah tanam 
dengan intensitas serangan hama dapat dilihat pada Gambar 1.

Gambar 1 menunjukkan bahwa intensitas serangan hama terung pada umur satu sampai empat minggu setelah tanam belum berbeda nyata karena intensitas serangan hama yang dimiliki kedua perlakuan menunjukan hasil yang sama pada masing-masing perlakuan, namun pada minggu ke empat dan minggu ke enam setelah tanam telah menunjukan hasil berbeda nyata $\mathrm{P} 1=0,91 \%$, sedangkan $\mathrm{P} 2=$ $0,76 \%$ dan pada minggu ke enam $\mathrm{P} 1=1,71 \%$ dibanding $\mathrm{P} 2=0,76 \%$. Jadi $\mathrm{P} 2$ memberikan pengaruh beda nyata dibanding P1.

Berdasarkan hasil analisis statistik uji standar error, pemberian pestisida anorganik (Decis) dan pestisida nabati daun pepaya untuk pengendalian hama pada tanaman terung, memberikan perbedaan yang efektif dari perbandingan terhadap masing-masing perlakuan P1 dan P2. Pengamatan yang dilakukan yaitu Intensitas serangan hama yang menimbulkan gejala kerusakan helaian daun yang rusak (\%), dimulai pada umur 7 hari setelah tanam dan dilakukan setelah aplikasi pestisida anorganik $0,25 \mathrm{ml} /$ liter air pada plot $\mathrm{P} 1$ dan pestisida nabati daun pepaya $20 \mathrm{ml} /$ liter air pada plot $\mathrm{P} 2$.

Berdasarkan hasil analisis statistik standar error yang telah dilakukan didapatkan hasil bahwa pemberian pestisida nabati daun pepaya $\mathrm{P} 2$ terhadap pengendalian hama tanaman terung menunjukan bahwa pada pengamatan minggu ke satu dan kedua belum ada intensitas serangan hama terhadap masing-masing perlakuan, pada minggu ketiga sampai minggu ke enam sudah ada intensitas serangan hama dan pada minggu ke lima dan ke enam P2 menunjukkan berbeda nyata terhadap intensitas serangan hama dibanding P1, karena P2 dapat menstabilkan intensitas serangan hama sedangkan P1 menghasilkan intensitas serangan hama yang tinggi hal ini didukung dengan beberapa pendapat berikut.

Kandungan daun pepaya yaitu zat papain juga bekerja secara aktif sebagai racun perut yang masuk ke dalam tubuh atau memberikan respons terhadap kutu daun sehingga menurunkan aktifitas makan dari kutu daun. Sistem kerja zat papain sebagai racun perut didalam tubuh kutu daun yaitu diserap oleh dinding-dinding yang ada pada organ pencernaan kutu daun kemudian akan dihantarkan ke pusat saraf kutu daun sehingga akan berpotensi memberikan tekanan serta menurunkan proses metabolisme organ dalam dan menghambat aktivitas makan kutu daun sehinnga menyebabkan kutu daun mengalami kematian. Hal ini ditambah dengan penjelasan (Dono, et al, 2008) yaitu bahwa residu pestisida menyebabkan aktivitas makan serangga menurun bahkan dapat terhenti, dan serangga juga menunjukkan penurunan aktivitas gerakan.

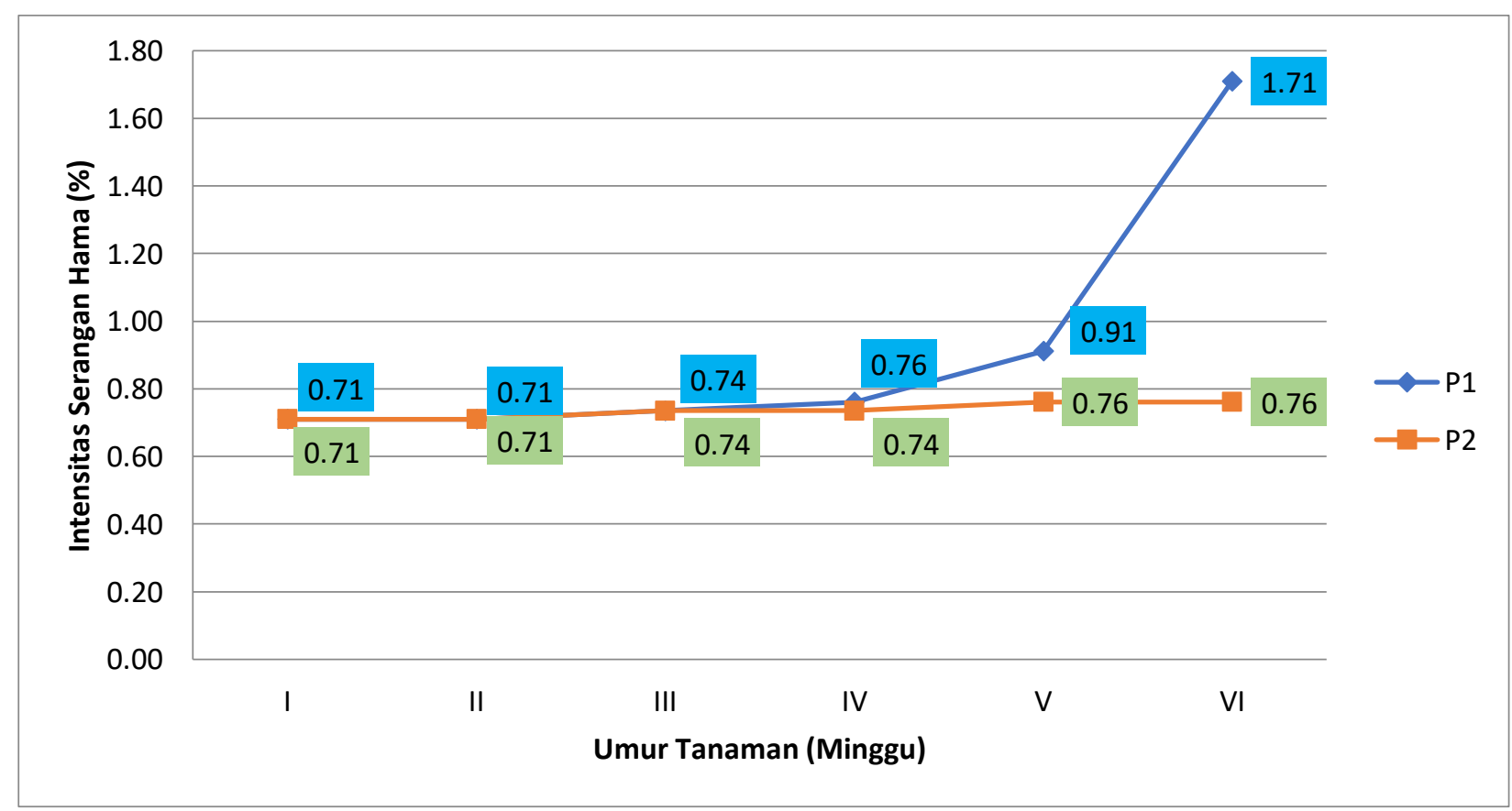

Gambar 1. Grafik intensitas serangan hama terung pada umur satu sampai enam minggu setelah tanam 
Daun papaya juga terdapat zat flavonoid yang bekerja sebagai racun saraf yang diduga bisa menyebabkan kutu daun mengalami penurunan aktivitas gerak, dan dipertajam dengan pendapat (Hasnah dan Nasril, 2009) menjelaskan bahwa senyawa flavonoid dapat menimbulkan kelayuan pada saraf serta kerusakan pada spirakel yang mengakibatkan serangga tidak bisa bernafas dan akhirnya mati.

Adanya enzim papain pada daun Carica papaya sehingga efektif untuk mengendalikan ulat dan hama penghisap hal ini dikarenakan enzim papain juga pada getah secara alami yang menyebabkan serangga menjadi lemah melalui daya racun dan toksitisitas atau nati nutrisi (Jeane, et al, 2013). Senyawa papain merupakan racun kontak yang masuk ke dalam tubuh ulat akan meyebabkan terganggunya akivitas makan ulat daun sehingga menurunnya aktivitas makan ulat daun secara perlahan-lahan dan mati. Hal ini didukung oleh pendapat Trizelia (2001), residu pestisida menyebabkan aktivitas makan serangga menurun bahkan dapat terhenti. Selain itu, serangga juga menunjukkan penurunan akitivitas gerakan seperti dari cepat menjadi lambat dan akhirnya mati.

\section{Evaluasi Penyuluhan}

Evaluasi penyuluhan tentang penerapan teknologi pestisida nabati daun papaya untuk pengendalian hama terung bertujuan untuk mengetahui sejauhmana tingkat adopsi kelompok Wanita tani terhadap inovasi teknologi yang disampaikan. Data yang diperoleh ditabulasi diperoleh skor penilaian sebagai berikut :

\section{Perubahan tingkat pengetahuan}

Data hasil evaluasi awal untuk tingkat pengetahuan dari hasil tabulasi atau pertanyaaan yang berkenaan dengan tingkat pengetahuan pada kuisioner. Dengan demikian kualitas pengetahuan tentang pestisida nabati daun pepaya untuk pengendalian hama terung, sebagai berikut:

Jumlah skor $=146$

Skor tertinggi yang diperoleh $=28 \times 5 \times 3=420$

Skor terendah yang diperoleh $=28 \times 5 \times 1=140$

Pengetahuan $=\frac{146}{420} \times 100 \%=34,76 \%$

Jika digambarkan dengan garis continuum, maka hasilnya dapat dilihat pada Gambar 2.

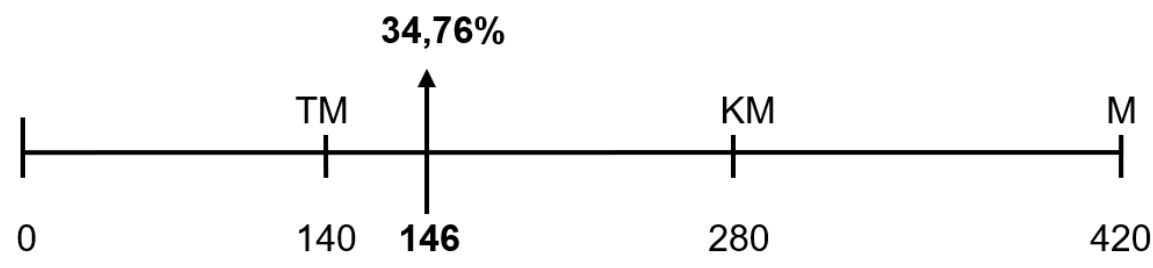

Gambar 2. Garis continuum hasil evaluasi awal aspek pengetahuan

Hasil pengukuran dengan garis continiuum maka dapat diketahui bahwa tingkat pengetahuan responden sebelum penyuluhan tentang teknologi pestisida nabati daun pepaya untuk pengendalian hama terung berada pada kategori Kurang Mengetahui (KM). Hal ini disebabkan karena responden belum mendapatkan informasi tentang teknologi pestisida nabati daun pepaya untuk pengendalian hama.

Hasil evaluasi akhir untuk tingkat pengetahuan responden diperoleh nilai sebagai berikut:
Jumlah skor $=380$

Skor tertinggi yang diperoleh $=28 \times 5 \times 3=420$

Skor terendah yang diperoleh $=28 \times 5 \times 1=140$

Pengetahuan $=\frac{335}{420} \times 100 \%=79,76 \%$

Hasil yang diperoleh jika digambarkan dengan garis continuum dapat dilihat pada Gambar 3. Hasil pengukuran dengan garis continuum menunjukkan bahwa hasil evaluasi akhir tingkat pengetahuan responden terhadap teknologi pestisida daun pepaya untuk pengendalian hama terung berada pada kategori mengetahui dengan nilai yang diperoleh sebanyak 335 atau $79,76 \%$. 


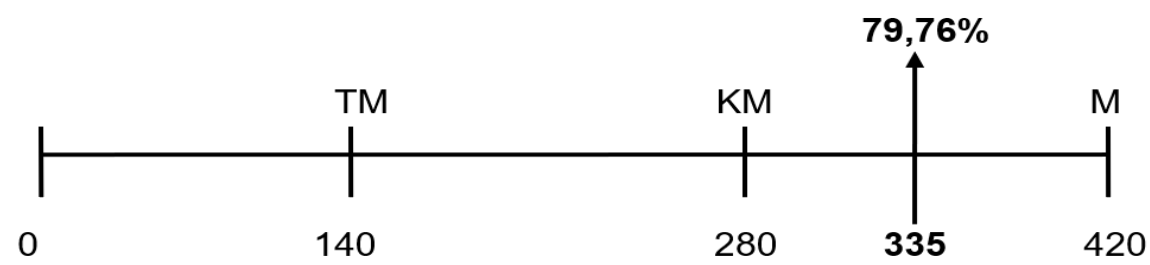

Gambar 3. Garis continuum hasil evaluasi akhir aspek pengetahuan

\section{Skala sikap}

Penilaian terhadap sikap berdasarkan dari adanya stimulasi atau rangsangan melalui indera terhadap suatu objek dimana sikap belum merupakan tindakan atau aktivitas akan tetapi merupakan redeposisi tingkah laku petani. Hasil dari penilaian sikap menunjukkan petani menerima atau tidak terhadap teknologi yang disuluhkan.
Berdasarkan data hasil evaluasi awal untuk mengetahui sikap, sebagai berikut:

Jumlah skor $=145$

Skor tertinggi yang diperoleh $=28 \times 5 \times 3=420$

Skor terendah yang diperoleh $=28 \times 5 \times 1=140$ Sikap $=\frac{145}{420} \times 100 \%=34,52 \%$

Hasil yang diperoleh, jika digambarkan dengan garis continuum dapat dilihat pada Gambar 4.

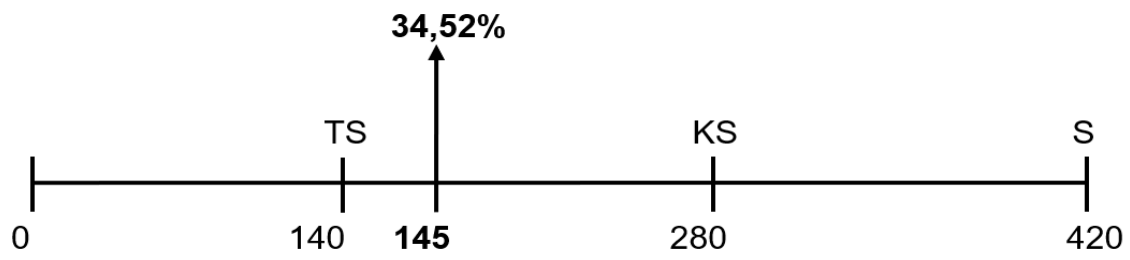

Gambar 4. Garis continuum hasil evaluasi awal aspek sikap

Hasil pengukuran dengan garis continuum, menunjukkan bahwa sikap responden berada pada kategori Kurang Setuju (KS). Dengan nilai yang diperoleh sebanyak 145 atau $34,52 \%$. Hal ini dapat dipengaruhi oleh tingkat pengetahuan sebelumnya yaitu masih taraf kurang memahami sehingga masih ada hal-hal yang menimbulkan sikap kurang setuju responden.

Sikap kurang setuju responden tersebut dapat mempengaruhi dalam pengambilan keputusan. Sikap tersebut dapat dihilangkan dengan menyakinkan responden bahwa cara-cara yang ditawarkan dalam pembuatan pestisida nabati dapat menjamin kelestarian lingkungan. Hasil evaluasi akhir yang diperoleh dari responden setelah dilakukan penyuluhan diperoleh skor sebagai berikut:

Jumlah skor $=339$

Skor tertinggi yang diperoleh $=28 \times 5 \times 3=420$

Skor terendah pada kuesioner $=28 \times 5 \times 1=140$ Sikap $=\frac{339}{420} \times 100 \%=80,71 \%$

Jika digambarkan dengan garis continuum dapat dilihat pada Gambar 5 .

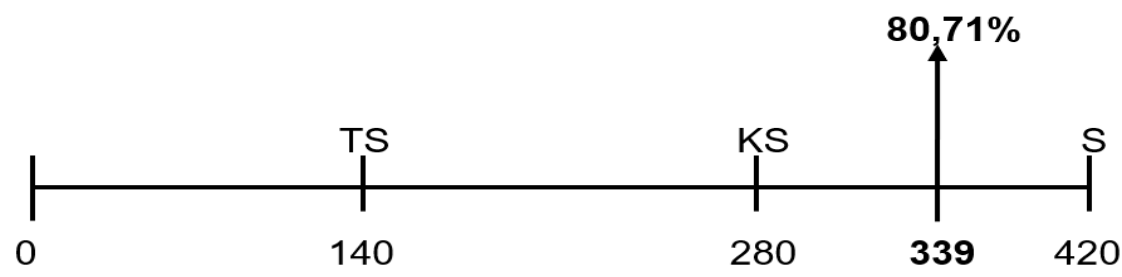

Gambar 5. Garis continuum hasil evaluasi akhir aspek sikap 
Hasil evaluasi akhir pada aspek sikap responden berada pada kategori setuju dengan nilai sebanyak 339 atau $80,71 \%$. Ini menunjukan bahwa tingkat adopsi terutama minat petani responden menyetujui teknologi yang telah disuluhkan.

\section{Keterampilan}

Keterampilan merupakan Tindakan atau aktivitas terhadap suatu objek atau kecendrungan bertindak atas penilaian dari sikap sehingga terjadi keyakinan untuk melakuan objek tersebut atau melakukan inovasi yang diberikan. Berdasarkan data hasil evaluasi awal untuk mengetahui keterampilan pada saat pendataan responden.

Jumlah skor $=143$

Skor tertinggi yang diperoleh $=28 \times 5 \times 3=420$

Skor terendah yang diperoleh $=28 \times 5 \times 1=140$

Keterampilan $=\frac{143}{420} \times 100 \%=34,04 \%$

Jika digambarkan dengan garis continuum dapat dilihat pada Gambar 6 .

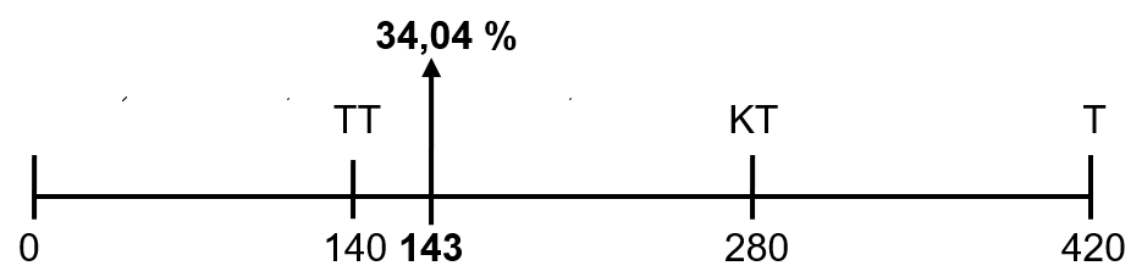

Gambar 6. Garis continuum hasil evaluasi awal aspek keterampilan

Berdasarkan hasil awal dengan menggunakan garis continuum berada pada kategori Kurang Terampil (KT). Hal ini terjadi disebabkan karena pengetahuan responden sebelum kegiatan penyuluhan masih berada pada kurang mengetahui dan sikapnya kurang setuju terhadap teknologi pestisida nabati untuk pengendalian hama.
Sedangkan hasil evaluasi akhir yang diperoleh setelah penyuluhan sebagai berikut:

Jumlah skor $=326$

Skor tertinggi yang diperoleh $=28 \times 5 \times 3=420$

Skor terendah yang diperoleh $=28 \times 5 \times 1=140$ Keterampilan $=\frac{326}{420} \times 100 \%=77,61 \%$

Jika digambarkan dengan garis continuum ditampilkan pada gambar 7 .

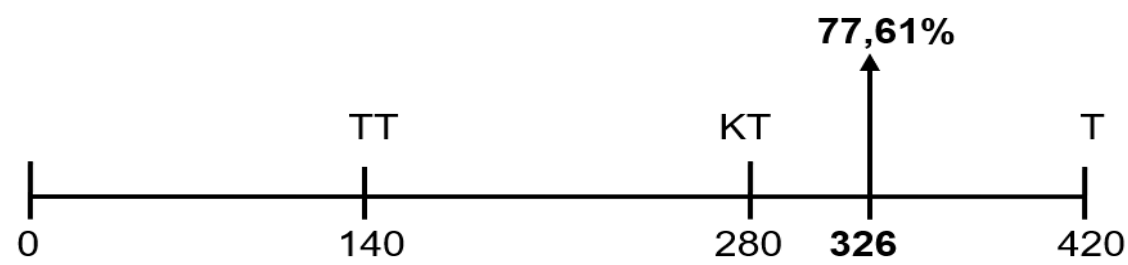

Gambar 7. Garis continuum keterampilan evaluasi akhir

Hasil evaluasi akhir pada aspek keterampilan responden terhadap penyuluhan teknologi pestisida nabati daun pepaya untuk pengendalian hama terung berada pada kategori terampil $77,61 \%$, hal ini berarti bahwa responden terampil. Dengan keterampilan tersebut, diharapkan agar responden selalu melakukan dan menerapkan teknologi pembuatan pestisida nabati dan mengaplikasikannya.

Untuk mengetahui perubahan dan peningkatan perolehan nilai responden persentasi dari nilai maksimum pada tingkat pengetahuan, sikap dan keterampilan, maka dapat disajikan rekapitulasi pada Tabel 1 .

Tabel 1 menunjukkan bahwa penyuluhan dengan materi teknologi pestisida nabati daun pepaya untuk pengendalian hama terung dapat mengubah pengetuhuan, sikap dan keterampilan responden dari kategori kurang mengetahui $(34,76 \%)$ sebelum mengikuti penyuluhan meningkat ke kategori mengetahui $(79,76 \%)$ setelah mengikuti penyuluhan. Perubahan yang sama juga terjadi pada aspek sikap yaitu meningkat dari kategori kurang setuju $(34,54 \%)$ 
meningkat ke kategori setuju (80,71\%). Aspek keterampilan meningkat dari $(34,04 \%)$ ke $(77,61 \%)$. Perpaduan media berupa folder, dan menggunakan benda sesungguhnya, demonstrasi cara yang setiap saat perkembangannya dapat dipantau dan didukung dengan adanya perbedaan antara dua perlakuan pada pengendalian hama tanaman terung memunculkan daya tarik tersendiri sehingga responden dapat memahami materi yang disuluhkan.

Tabel 1. Rata-rata tingkat pengetahuan sikap dan keterampilan responden

\begin{tabular}{llccccccc}
\hline \multirow{2}{*}{ No } & \multirow{2}{*}{ Deskripsi } & \multirow{2}{*}{$\begin{array}{c}\text { Skor } \\
\text { maks }\end{array}$} & $\begin{array}{c}\text { Tes } \\
\text { awal }\end{array}$ & Persentase & $\begin{array}{c}\text { Tes } \\
\text { akhir }\end{array}$ & Persentase & Nilai & Persentase \\
\hline 1 & Pengetahuan & 420 & 146 & $34,76 \%$ & 335 & $79,76 \%$ & 189 & $32,8 \%$ \\
2 & Sikap & 420 & 145 & $34,54 \%$ & 339 & $80,71 \%$ & 194 & $33,7 \%$ \\
3 & Keterampilan & 420 & 143 & $34,04 \%$ & 336 & $77,61 \%$ & 193 & $33,5 \%$ \\
\hline
\end{tabular}

\section{Efektivitas Penyuluhan}

Efektivitas penyuluhan di Kelurahan Bontoramba pada Kelompok Wanita Tani Bunga Tulip yang telah dilaksanakan dapat diketahui dengan menggunakan rumus berikut:

$$
\mathrm{EP}=\frac{\mathrm{Ps}-\mathrm{Pr}}{\mathrm{N} 4 \mathrm{Q}-\mathrm{Pr}} \times 100 \%
$$

Keterangan :

$$
\begin{array}{ll}
\mathrm{Ps} & =\text { Post test } \\
\mathrm{Pr} & =\text { Pree test } \\
\mathrm{N} & =\text { Jumlah responden } \\
4 & =\text { Nilai tertinggi } \\
\mathrm{Q} & =\text { Jumlah pertanyaan } \\
100 \% & =\text { Pengetahuan yang ingin dicapai } \\
\mathrm{Ps}-\mathrm{Pr} & =\text { Peningkatan pengetahuan } \\
\mathrm{N} 4 \mathrm{Q}-\mathrm{Pr}=\text { Nilai kesenjangan } & \\
\mathrm{EP}= & \frac{1010-434}{(28.3 .15)-434} \times 100 \%=69,7 \%
\end{array}
$$

$<33,33 \%=$ Kurang efektif; 33,34- 66,66\% = Cukup efektif; $>66,67 \%=$ Efektif. Berdasarkan pada hasil penyuluhan awal dan penyuluhan akhir sebanyak $69,7 \%$ maka efektifitas penyuluhan dapat dikategorikan efektif.

\section{KESIMPULAN}

1. Aplikasi pestisida nabati daun papaya pada tanaman terung dapat mengendalikan hama tanaman terung secara efektif dengan dosis 20 $\mathrm{ml} /$ liter air, menekan intensitas serangan hama tanaman terung hasil perlakuan terbaik yaitu pestisida nabati daun pepaya (P2) dengan hasil berbeda nyata $0,76 \%$ sedangkan pestisida anorganik (P1) 1,71\%. Hal demikian karena pestisida nabati daun pepaya memiliki bahan aktif papain baik secara langsung maupun secara sistemik dapat mengurangi aktivitas hama dan bahkan hama akan mati.

2. Hasil evaluasi penyuluhan menunjukan respons petani terhadap pestisida nabati daun pepaya pada tanaman terung menunjukan peningkatkan pengetahuan 32,8\%, sikap $33,7 \%$ dan keterampilan 33,5\%. Pelaksanaan penyuluhan dinyatakan $69,7 \%$ berada pada kategori Efektif.

\section{DAFTAR PUSTAKA}

Chen, C., Qian, Y., Chen, Q., Tao, C., Li, C. dan Li, Y, 2011. Evaluation of Pesticide Residues in Fruits and Vegetables From Xiame, Food Control 22 : 1114-1120.

Daripah, E.H, Budiyono dan M. Julaeni, 2010. Analisis Perilaku Konsumen dalam Pembelian Produk Sayuran di Pasar Modern Kota Bekasi. Jurnal Agribisnis dan Pengembangan Wilayah 1(2), 24-37.

Djunaedy, A., 2009. Biopestisida sebagai Pengendalian Organisme Pengganggu Tanaman (OPT) yang Ramah Lingkungan. Jurnal Embryo 6(1) : 88-95.

Dono, Danar dan Rismanto. 2008. Aktifitas Residu Ekstrak Biji Barringtonia Asiatica (L.) Kurz terhadap Larva Crocidolomia Pavonana $F$. (Lepidoptera: Pyralidae). Jurnal Agrikultura.volume 19, nomor 3. ISSN.0853-2885. Hal 184-189.

Duaja, MD, Arzita, Simanjuntak P, 2003. Analisis Tumbuh dan Varietas Terung (Solanum melingena, L) pada Perbedaan Jenis Pupuk Organik Cair Bioplantae, 2(1) : 33-39. 
Ginting, E. 1991. Metode Kuliah Kerja Lapang. Universitas Brawijaya, Malang.

Grdisa, M., and K. Grsic., 2013. Botanical Insectisides in Plant Protection. Agriculturae Conspectus Scientificus 78(2) : 85-93.

Hasnah dan Nasril.2009. Efektivitas Ekstrak Buah Mengkudu (Morinda citrifolia L.) terhadap Mortalitas Plutella xylostella L. pada Tanaman Sawi. Jurnal Floratek 4 : 29-40. Fakultas Pertanian Unsyiah Banda Aceh.

Intan, Kurnia silvi, Kismiyati dan Kusnoto, 2012.

Lama Perendaman Ikan Komet (Carassius auratus auratus) dalam Perasan Daun Pepaya (Carica papaya) Sebagai Pengendali Argulus Control. Fakultas Perikanan dan Kelautan Universitas Airlangga, Surabaya.

Jeana, S. Macalood, J.V. Helen, D.B. Renato, G. Jessie. Gorospe, and C.R. Elnor, 2013. Chemical Analysis of Carica papaya, L, Crude latex. American Journal of Plant Sciences 4 : 1941-1948.

Kadir DAA, Kadirman, Jamaluddin, 2015. Penerapan Sistem Osmotic Dehydration Untuk Mengurangi Kadar Lemak Keripik Buah pada Gorengan Tekanan Hampa Udara. Jurnal Pendidikan Terno Pertan 1 : 22-29.

Padmowihardjo, S., 2002. Evaluasi Penyuluhan Pertanian. Modul Universitas Terbuka. Jakarta.
Pracaya, 2007. Hama dan Penyakit Tumbuhan. Penebar Swadaya, Jakarta.

Srinivasa R, 2009. Insect and Mite Pests on Eggplant : A Filed Guide for Identification and Management. AVRDC - The World Vegetable Center, Shanhua, Taiwan AVRDC Publication No. 09-729.64p.

Suharyon, S. Edi dan Adi, 2010. Kajian Keragaan Pasar Tanaman Sayuran dan Dampaknya Terhadap Hari Besar Keagamaan. Sosio Ekonomika Bisnis : 44-49.

Trizelia, 2001. Makalah Pemanfaatan Bacillus thuringiensis Untuk Pengendalian Hama Crocidolomia binotalis. IPB. Bogor. htt p:/ /www. rud yct.com/PPS 702- 03 112/trizeli a.html diakses tanggal $19 \mathrm{Mei}$ 2017.

Untung, K, 2007. Pengantar Pengelolaan Hama Terpadu. Gadjah Mada University Press, Yogyakarta.

Wiratno, S dan I.M. Trisawa, 2012. Perkembangan Penelitian, Formulasi dan Pemanfaatan Pestisida Nabati. Balai Pengkajian Teknologi Pertanian Sumatera Selatan.

Wowor EK, Kaligis JB, CaroliusCS, 2017. Persentase Serangan Leucinodes orbonalis Gueene (Lepidotera, Crambidae) pada Buah Terung di Kelurahan Wailan dan Kakaskasen di Kecamatan Tomohon Utama. Cocos 1(3) : $1-11$. 